\title{
ЕКОЛОГІЗАЦІЯ БІЗНЕСУ ЯК ІНСТРУМЕНТ ПІДВИЩЕННЯ РІВНЯ ЙОГО БЕЗПЕКИ
}

\section{ECOLOGIZATION OF BUSINESS AS AN INSTRUMENT FOR INCREASING ITS SECURITY}

\author{
Зайченко Катерина Сергіївна \\ кандидат економічних наук, \\ Державний університет «Одеська політехніка» \\ ORCID: https://orcid.org/0000-0002-0975-2175 \\ Болховська Анна Петрівна \\ здобувачка освітнього ступеня «Магістр», \\ Державний університет «Одеська політехніка» \\ ORCID: https://orcid.org/0000-0003-0951-1926

\section{Zaichenko Kateryna, Bolkhovska Anna \\ Odessa Polytechnic State University}

\begin{abstract}
У статті проаналізовано підходи до трактування поняття «екологізація» вітчизняних та зарубіжних вчених та виділено ключові ознаки, за якими його розглядають, зокрема такі: розвиток; зв'язок між техніко-технологічною та економічною складовими безпеки бізнесу; різноманітність соціально-економічної діяльності; свідомість та відповідальність людства; сталий розвиток для галузей; зменшення деструктивного впливу; процес та підтримка низки поколінь людей. Визначено, що екологізація впливає не лише на екологічну сферу розвитку, а й на економічну та соціальну. Проаналізовано переваги та недоліки, що можуть виникнути внаслідок запровадження заходів екологізації відповідно кожної з них. Виявлено, що в аспекті екологічної ссрери екологізація підвищує рівень екологічної складової безпеки бізнесу; економічної - рівень фрінансової складової; соціальної - рівень кадрової та інтелектуальної складової.
\end{abstract}

Ключові слова: екологізація, бізнес, безпека бізнесу, заходи екологізації, раціональне споживання, ефект.

В статье проанализированы подходы к трактовке понятия «экологизация» отечественных и зарубежных ученых. Выделены ключевые признаки, по которым его рассматривают: развитие; связь между технико-технологической и экономической элементами безопасности бизнеса; разнообразие социально-экономической деятельности; сознание и ответственность человечества; устойчивое развитие для отраслей; уменьшение деструктивного воздействия; процесс и поддержка ряда поколений людей. Определено, что экологизация влияет на экологическую, экономическую, социальную сферы развития. Проанализированы преимущества и недостатки, которые возникают вследствие внедрения мер экологизации в соответствии с ними. Установлено, в аспекте экологической сферы экологизация повышает уровень экологической составляющей безопасности бизнеса; экономической - уровень финансовой; социальной - уровень кадровой и интеллектуальной.

Ключевые слова: экологизация, бизнес, безопасность бизнеса, меры экологизации, рациональное потребление, эфрфект.

The article analyzes the approaches of domestic and foreign scientists to the interpretation of the concept ecologization and highlights the key features by which it's considered. The following features have been identified: development, the link between technological and economic components of business security, the diversity of socio-economic activities, human consciousness and responsibility, sustainable development for industries, reducing destructive impact, the process and support of generations. It is determined that ecologization affects not only the environmental sphere of development, but also economic and social. The advantages and disadvantages that may arise as a result of the introduction of environmental measures are analyzed. In the economic sphere, increasing the trend of environmental awareness among the population creates opportunities to expand the base of customers who have a conscious attitude to the conscious use and protection of the environment. This will increase the target audience of the business, increase profits and enter new markets. At the same time, the possible increase in current costs for the implementation of these measures will have a smaller negative effect than the positive one. In the ecological sphere, the introduction of environmental measures has no significant shortcomings. Choosing the direction 
of ecologization, its benefits have both, long-term effect, aimed at developing of "green markets" and improving the environment, and short-term, with improving product quality and the environmental component of business security. In the social sphere, business may face the problem of personnel who will be ready to implement and adapt ecologization processes not only from the professional component, but also mentally. After all, employees must also uphold the values of business and chosen vector of its development. At the same time, solving this problem by retraining staff, involving professionals to upgrade their skills will improve the intelligent business security subsystem and change its staff in terms of their competencies.

Keywords: ecologization, business, business security, environmental measures, rational consumption, effect.

Постановка проблеми. 3 кожним роком зростає екологічна обізнаність суспільства та набуває розповсюдження серед населення раціональне користування. Дослідження, що проводяться науковцями в різних країнах світу, призвели до розуміння, що захист навколишнього середовища має важливий вплив на стан здоров'я людини, добробут населення та імідж країни в цілому. В свою чергу недобросовісна екологічна практика призводить до значних негативних соціальних й економічних ефректів. Такі негативні явища як глобальне потепління, зменшення озонового слою, забрудненість повітря та води, виснаженість ґрунтів, зменшення природних ресурсів вже перестали мати локальний характер. Таким чином вирішення вище вказаних проблем вже давно перейшло з площини регіонального або національного на глобальний рівень: створюються міжнародні організації, об'єднання, що проводять аналіз та дослідження причин, які їх провокують, фрормують такі умови, що націлені на збереження навколишнього середовища та попередження виникнення негативних природних явищ. Як наслідок, особливої актуальності серед науковців та вчених набуло поняття екологізації. Впровадження ії засад у діяльність бізнесу спроможне зменшити рівень забрудненості навколишнього середовища, налагодити раціональне використання природних ресурсів та забезпечити мінімізацію антропогенного впливу на природні процеси відтворення.

Аналіз останніх досліджень і публікацій. Дослідженню теоретичних засад формування сутності екологізації були присвячені роботи багатьох вітчизняних вчених, серед яких І. Варламова, С. Варламова, О. Колонькова, Л. Мельник та інших. Зарубіжними вченими також приділено достатньо уваги дослідженню теоретичного та практичного змісту екологізації, зокрема роботи Фанг С.Р., Яо Х., Чжао Л., Ю 3., Цзян X. Аспекти фрормування напрямів екологізації економіки та впровадження ії засад у діяльність бізнесу висвітлені у наукових працях вітчизняних вчених, серед яких В. Гобела, А. Дубодєлова, Л. Чумак та інших.
Виділення невирішених раніше частин загальної проблеми. В той же час досі залишаються невизначеними аспекти екологізації у розрізі їі впливу на рівень окремих підсистем та безпеки бізнесу в цілому .

Постановка завдання. Метою дослідження $\epsilon$ визначення впливу екологізації бізнесу на рівень його безпеки в цілому та окремих її підсистем. Досягнення мети забезпечить виконання таких завдань:

- дослідження сутності поняття «екологізація» відносно ключової ознаки, що фрормулюється вітчизняними та зарубіжними вченими;

- виявлення основних сорер, в яких відображається есрект для бізнесу від впровадження напрямів екологізації;

- аналіз переваг та недоліків впровадження екологізації та її вплив на рівень безпеки бізнесу;

Виклад основного матеріалу дослідження. Останніми роками суспільство почало все більше помічати проблеми екології та стану навколишнього середовища. Через надмірне збільшення обсягів промислового виробництва та виснажливе використання природних ресурсів вони зіткнулось 3 відповідними проблемами щодо більшої кількості природних катаклізмів, погіршення природного біорізноманіття, зміни клімату, виснаженості та погіршення якісних властивостей ґрунтів та інше. Саме екологізація має змогу мінімізувати нанесену шкоду, за рахунок інноваційних технологій зменшити можливі збитки, а також збалансувати взаємовідносини людини і природи.

У 1992 р. у Ріо-де-Жанейро проходила конфреренція ООН з питань навколишнього середовища і економічного розвитку, де розглядався «Порядок денний на XXI століття». У резолюції було запропоновано ідею так званого «сталого розвитку», а у 1997 р. на XIX спеціальній сесії Генеральної Асамблеї ООН була розроблена та прийнята конкретна програма щодо дій та впровадження цієї ідеї в практику господарювання у всіх населених пунктах та країнах світу у XXI столітті [1].

Саме реалізація ідей сталого розвитку має забезпечуватись екологізацією економіки кра- 
їни в процес господарювання, що буде слугувати усуненню екологічних проблем на мікрорівні також. Сутність поняття «екологізація» охоплює різні сорери соціально-економічної системи, містить власні напрями, при цьому перетинаючись з іншим теоретичним базисом в області екології та економіки. Проаналізуємо підходи науковців до трактування терміну «екологізація» та визначимо його ключовий аспект (табл. 1).

Проведений аналіз показав, що дослідженню змісту поняття «екологізація» присвячено роботи багатьох вітчизняних та зарубіжних науковців. Основними його змістовними аспектами $\epsilon$ розвиток, зв'язок між технікотехнологічною та економічною складовими безпеки бізнесу, різноманітність соціальноекономічної діяльності, свідомість та відповідальність людства, сталий розвиток для галузей, зменшення деструктивного впливу, процес та підтримка низки поколінь людей. Це підтверджує те, що екологізація не обмежується лише екологічним напрямом дії, а має вплив на окремі процеси бізнесу та розвитку суспільства, в тому числі економічний та соціальний аспекти.

Впровадження екологізації $€$ ще не досить розвиненою практикою вітчизняних суб'єктів бізнесу. Це пояснюється такими чинниками: відсутність державних програм, що стимулювали б підприємців запроваджувати природоохоронні заходи, слабкий рівень їх підтримки та актуалізації на макрорівні, низька ступінь обізнаності населення, їх інфрормаційна підтримка та ін. Екологізація має певні переваги та недоліки, аналіз яких дасть змогу більш чітко визначити ії роль для бізнесу та рівня його безпеки. Будь-який процес або захід, що впроваджується суб'єктом бізнесу, слід розглядати в аспекті ефректу, який буде фрормуватися

Таблиця 1

Порівняльна характеристика підходів до формулювання поняття «екологізація»

\begin{tabular}{|c|c|c|}
\hline Автор & Визначення поняття («Екологізація - це...») & Ключова ознака \\
\hline $\begin{array}{c}\text { Лучано Еспіноса } \\
\text { [2] }\end{array}$ & продовження розвитку. & розвиток \\
\hline $\begin{array}{l}\text { С. Варламова, } \\
\text { І. Варламова } \\
{[3, \text { с. 2] }}\end{array}$ & \begin{tabular}{|l|} 
процес постійної і послідовної розробки \\
та впровадження у процес виробництва нових \\
технологічних і управлінських рішень, які дають \\
можливість підвищувати ефективність використання \\
природних ресурсів із збереженням чи поліпшенням \\
якості довкілля.
\end{tabular} & $\begin{array}{l}\text { зв'язок між техніко- } \\
\text { технологічною } \\
\text { та економічною } \\
\text { складовими безпеки } \\
\text { бізнесу }\end{array}$ \\
\hline К. Мішев [4] & $\begin{array}{l}\text { підхід або спосіб розуміння широкого спектру } \\
\text { соціальних та економічних видів діяльності, } \\
\text { які з самого початку враховують вплив на } \\
\text { навколишнє середовище та збереження. } \\
\end{array}$ & $\begin{array}{l}\text { різноманітність } \\
\text { соціально- } \\
\text { економічної } \\
\text { діяльності } \\
\end{array}$ \\
\hline $\begin{array}{l}\text { Н. Пустовіт, } \\
\text { О. Колонькова, } \\
\text { О. Пруцакова, } \\
\text { Г. Тарасюк, } \\
\text { Ю. Солобай } \\
\text { [5, с. 18] }\end{array}$ & $\begin{array}{l}\text { процес зміни свідомості, що виражається у } \\
\text { переосмисленні зв'язків між природою, людиною, } \\
\text { суспільством і культурою у бік визнання безумовної } \\
\text { відповідальності стосовно природи і турботи про неї. }\end{array}$ & $\begin{array}{c}\text { свідомість } \\
\text { та відповідальність } \\
\text { суспільства }\end{array}$ \\
\hline $\begin{array}{l}\text { Інь Дж., } \\
\text { Чжен Х., } \\
\text { Фанг С. [4] }\end{array}$ & $\begin{array}{l}\text { стає важливим з точки зору попиту і глоба } \\
\text { тенденцією, яка прагне до сталого розвит }\end{array}$ & $\begin{array}{l}\text { сталий розвиток } \\
\text { для галузей }\end{array}$ \\
\hline $\begin{array}{l}\text { Л. Мельник } \\
{[6, \text { с. } 216]}\end{array}$ & $\begin{array}{l}\text { цілеспрямований процес перетворення економіки, } \\
\text { що зорієнтований на зменшення інтегрального } \\
\text { деструктивного впливу процесів виробництва та } \\
\text { споживання товарів і послуг у розрахунку } \\
\text { на одиницю сукупного суспільного продукту }\end{array}$ & $\begin{array}{c}\text { зменшення } \\
\text { деструктивного } \\
\text { впливу }\end{array}$ \\
\hline $\begin{array}{c}\text { Фанг С.Р., } \\
\text { Яо Х., Чжао Л., } \\
\text { Ю 3., Цзян Х. [7] }\end{array}$ & $\begin{array}{l}\text { своєрідний процес, процес інтеграції організмів } \\
\text { з навколишнім середовищем. }\end{array}$ & процес \\
\hline Е. Семенюк [ & $\begin{array}{l}\text { прогрес у наданні екологічної сутності та змісту } \\
\text { будь-яким можливим об'єктам, щоб ресурсів } \\
\text { вистачило на підтримку нескінченної кількості } \\
\text { людських поколінь. }\end{array}$ & $\begin{array}{l}\text { підтримка низки } \\
\text { поколінь людей }\end{array}$ \\
\hline
\end{tabular}


в наслідку цих дій. Згрупуємо їх відповідно до есректу, що сорормується під впливом впроваджених заходів екологізації, а саме: економічний, екологічний та соціальний (табл. 2).

Проведений аналіз переваг та недоліків щодо впровадження заходів екологізації показав позитивний ефект на основні аспекти діяльності бізнесу. Щодо економічної сфрери, через збільшення тренду екологічної обізнаності серед населення [12-14] € можливості розширити базу клієнтів, які мають свідоме відношення до раціонального користування та охорони навколишнього середовища. Це дасть змогу збільшити цільову аудиторію бізнесу, підвищити прибутки та вийти на нові ринки збуту, в тому числі закордонні. При цьому можливе збільшення поточних витрат на впровадження цих заходів будуть мати менший негативний есрект, ніж отриманий позитивний.

щодо екологічної сорери, через направленість заходів екологізації на покращення стану довкілля, запровадження природоохоронних заходів немає суттєвих недоліків. Звісно, вони можуть виникати, але це залежить від конкретної сорери діяльності бізнесу. Обираючи напрям екологізації переваги для нього мають як довгостроковий ефрект, що проявляється в освоєнні «зелених ринків» та покращенні стану навколишнього середовища, так і короткостроковий, а саме підвищується якість продукції, покращується рівень екологічної складової безпеки бізнесу.

Відносно соціальної ссрери, бізнес може зіткнутися з проблемою кадрів, що не будуть готові до впровадження та адаптації процесів екологізації не лише з професійної точки зору, а й ментальної. Адже працівники мають також підтримувати цінності бізнесу та обраний вектор його розвитку. В той же час вирішення даної проблеми шляхом переквалісрікації кадрів, залучення фрахових спеціалістів для підвищення їх кваліфікації забезпечать покращення інтелектуальної підсистеми безпеки бізнесу та якісно змінять його кадровий склад в аспекті їх вмінь та навичок.

Екологізація економічної системи, може здійснюватися шляхом урахування екологічного фрактору при плануванні, ціноутворенні, інвестуванні, матеріально-технічному забезпеченні виробництва, мотивації та оплати праці, маркетинговій діяльності [15].

Тим самим екологізація має вплив на діяльність бізнесу не лише в екологічній ссрері, a і в інших аспектах, а саме економічній та соціальній, що в свою чергу прямо впливає на його розвиток в цілому та підвищує рівень свідомого ставлення населення до оптимального споживання, раціонального природокористування та захисту навколишнього середовища.

Висновки 3 проведеного дослідження. Сучасний стан довкілля потребує конкретних

Переваги та недоліки екологізації на вітчизняних підприємствах

\begin{tabular}{|c|c|c|}
\hline \multicolumn{3}{|c|}{ Переваги та недоліки екологізації на вітчизняних підпри } \\
\hline Ефрект & Переваги & Недоліки \\
\hline Економічний & $\begin{array}{c}\text { - зменшення витрат; } \\
\text { - збільшення прибутку; } \\
\text { - розширення клієнтської бази; } \\
\text { - освоєння нових ринків збуту; } \\
\text { покращення фрінансової підсистеми } \\
\text { безпеки бізнесу. }\end{array}$ & $\begin{array}{c}\text { - адаптація технології } \\
\text { виробництва; } \\
\text { - погіршення темпів Нтп; } \\
\text { - складність забезпечення } \\
\text { принципів ринкової економіки. }\end{array}$ \\
\hline Екологічний & $\begin{array}{c}\text { - покращення стану навколишнього } \\
\text { середовища; } \\
\text { - зменшення відходів та обсягів забруднення; } \\
\text { - орієнтація на «зелені ринки»; } \\
\text { - покращення якості продукції; } \\
\text { покращення екологічної складової } \\
\text { безпеки бізнесу. } \\
\end{array}$ & - \\
\hline Соціальний & 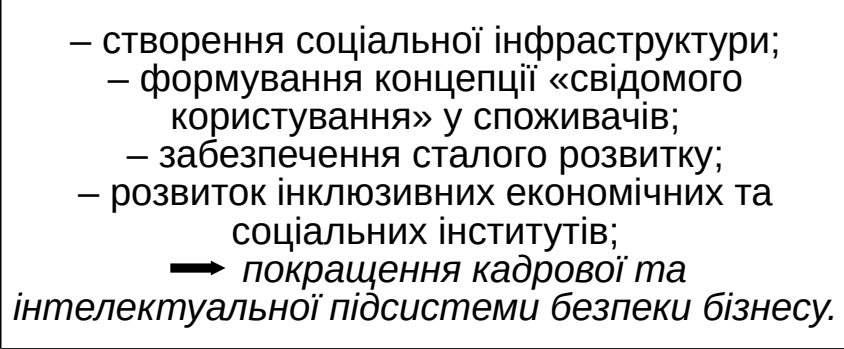 & $\begin{array}{c}\text { - високий рівень вимог } \\
\text { до працівників; } \\
\text { - низький рівень обізнаності } \\
\text { населення; } \\
\text { - зниження рівня соціального } \\
\text { захисту; } \\
\text { - домінування «фретишу } \\
\text { природи» над людськими } \\
\text { цінностями. }\end{array}$ \\
\hline
\end{tabular}

Таблиця 2

Джерело: розроблено автором на підставі [9-11] 
дій від людства та світової наукової спільноти. Основним інструментом запобігання та вирішення екологічних проблем має стати екологізація країни, в аспекті стратегічного iї розвитку, що в подальшому буде серед пріоритетних завдань на регіональному та локальному рівнях. Саме це стимулюватиме бізнес та населення розвивати напрями екологізації у своїй діяльності. Проведене дослідження виявило, що теоретичний зміст екологізації не обмежується лише впливом на екологічну складову, а має досить багатовекторний спектр, зокрема фрормування свідо- мості та відповідальності суспільства, різноманітність соціально-економічної діяльності та зв'язок між техніко-технологічною та економічною складовими безпеки бізнесу. Це створює підґрунтя для практичного його змісту, що підтверджується основними перевагами, які отримає бізнес від впровадження заходів екологізації у свою діяльність, зокрема зменшення відходів та обсягів забруднення, розвиток інклюзивних економічних та соціальних інститутів та покращення фрінансової, екологічної та кадрово-інтелектуальної підсистем безпеки бізнесу.

\section{СПИСОК ВИКОРИСТАНИХ ДЖЕРЕЛ:}

1. Чумак Л.Ф. Перспективи впровадження концепцій біоекономіки та її вплив на розвиток машинобудівних підприємств. Стійкий розвиток в умовах соціально-орієнтованої економіки : колективна монографія I ред. д.е.н., проф. В.В. Прохорова. Харків : Смугаста типографія, 2016. С. 89-97.

2. Espinosa L. Towards an Eco-Anthropology of the Common. Some Connections between Biology, Society, Ecology and History. Argos. 2013. Vol. 30(58). P. 107-144. URL: https://www.researchgate.net/publication/ 279038352_Towards_an_Eco-Anthropology_of_the_Common_Some_Connections_between_Biology_Society_ Ecology_and_History (дата звернення: 17.12.2021).

3. Варламова С.І. Екологізація промисловості в Україні: проблеми та перспективи. Ефективна економіка. 2016. № 1. URL: http://nbuv.gov.ua/UJRN/efek_2016_1_44 (дата звернення: 27.12.2021).

4. Yin, J., Zheng, X., \& Fang, S. The Dynamic Analysis of Tourism Industrial Ecologization in Mainland China: Its Status and Evolution. J Tourism Res Hospitality. 2018. Vol. 7. Issue 2. URL: https://www.scitechnol.com/peerreview/the-dynamic-analysis-of-tourism-industrial-ecologization-in-mainland-china-its-status-and-evolution-TYSK. php?article_id=7723 (дата звернення: 15.12.2021).

5. Екологізація освітнього простору сучасної загальноосвітньої школи : монограсрія / Н. Пустовіт, О. Колонькова, О. Пруцакова, Г. Тарасюк, Ю. Солобай. Харків : Друкарня Мадрид, 2016. 154 с.

6. Мельник Л.Г. Екологічна економіка : підручник. 3-тє вид., випр. і допов. Суми : ВТД Університетська книга, 2006. 367 c.

7. Fang, S.R., Yao, H., Zhao, L., You, Z., \& Jiang, H. Ecologization: an inevitable choice of Chinese modern urban sustainable development. In Advanced Materials Research. 2012. Vol. 524. P. 3573-3577. Trans Tech Publications Ltd. URL: https://www.scientific.net/AMR.524-527.3573 (дата звернення: 25.12.2021).

8. Semenyuk E.P. Role of informatics in the ecologization of society. Scientific and Technical Information Processing. 2012. Vol. 39. № 1. P. 1-12. DOI: https://doi.org/10.3103/S0147688212010029 (дата звернення: 11.12.2021).

9. Дубодєлова А.В. Організаційно-економічні механізми екологізації виробництва на вітчизняних підприємствах. Вісник Національного університету «Львівська політехніка». 2011. № 698. С. 156-162.

10. Гобела В.В. Економіко-безпекова екологізація: теорія і практика : монограсія. Львів : ЛьвДУВС, 2021. 244 c.

11. Зайченко К.С., Діма Н.І. Економічна безпека підприємства: сутність та роль. Ефективна економіка. 2021. № 5. URL: http://www.economy.nayka.com.ua/?op=1\&z=8900 (дата звернення: 15.12.2021).

12. Марушевський Г., Хікман Даг. «Зелений» бізнес для малих і середніх підприємств : посібник. Проект «Партнерство для розвитку міст». 2017. URL: http://pleddg.org.ua/wp-content/uploads/2017/11/SME-Guide-web.pdf (дата звернення: 19.12.2021).

13. Балюк С., Клаунінг Н., Четвертухіна Л., та Коваль-Гончар М. Екологічні тренди в Україні: погляд громадян. Звіт за результатами соціологічного дослідження. Київ : Фонд ім. Фрідріха Еберта, 2021. URL: http://library.fes.de/pdf-files/bueros/ukraine/17805.pdf (дата звернення: 15.12.2021).

14. Куць Н. Екологічна свідомість українців \& довкілля. Аналітичний документ. 2020. URL: http://epl.org.ua/ wp-content/uploads/2020/12/ekosvidomist.pdf (дата звернення: 21.12.2021).

15. Прокопенко О.В. Соціально-економічна мотивація екологізації інноваційної діяльності : монограсрія. Суми : Вид-во СумДУ, 2010. 395 с. 


\section{REFERENCES:}

1. Chumak, L.F. (2016) Perspektyvy vprovadzhennia kontseptsii bioekonomiky ta yii vplyv na rozvytok mashynobudivnykh pidpryiemstv [Prospects for the implementation of bioeconomy concepts and its impact on the development of machine-building enterprises]. In V.V. Prokhorov (Eds.). Stiikyi rozvytok v umovakh sotsialno-oriientovanoi ekonomiky, pp. 89-97. Kharkiv: Smuhasta typohrafiia. (in Ukrainian)

2. Espinosa, L. (2013) Towards an Eco-Anthropology of the Common. Some Connections between Biology, Society, Ecology and History. Argos, vol. 30(58), 107-144. Retrieved from: https://www.researchgate.net/publication/ 279038352_Towards_an_Eco-Anthropology_of_the_Common_Some_Connections_between_Biology_Society_ Ecology_and_History

3. Varlamova, S.I., Varlamova, I.S. (2016) Ekolohizatsiia promyslovosti v Ukraini: problemy ta perspektyvy [Ecologization of industry in Ukraine: problems and prospects]. Efektyvna ekonomika, 1. Retrieved from: http://nbuv.gov.ua/UJRN/efek_2016_1_44 (in Ukrainian)

4. Yin, J., Zheng, X., \& Fang, S. (2018) The Dynamic Analysis of Tourism Industrial Ecologization in Mainland China: Its Status and Evolution. J Tourism Res Hospitality, vol. 7, issue 2. Retrieved from: https://www.scitechnol.com/ peer-review/the-dynamic-analysis-of-tourism-industrial-ecologization-in-mainland-china-its-status-and-evolutionTYSK.php?article_id $=7723$

5. Pustovit, N., Kolonkova, O., Prutsakova, O., Tarasiuk, H., Solobai, Yu. (2016) Ekolohizatsiia osvitnoho prostoru suchasnoi zahalnoosvitnoi shkoly [Ecologization of the educational space of a modern secondary school]. Kharkiv: «Drukarnia Madryd». (in Ukrainian)

6. Melnyk, L.H. (2006) Ekolohichna ekonomika [Ecological economy] (3d ed.). Sumy: VTD «Universytetska knyha». (in Ukrainian)

7. Fang, S.R., Yao, H., Zhao, L., You, Z., \& Jiang, H. (2012) Ecologization: an inevitable choice of Chinese modern urban sustainable development. In Advanced Materials Research, vol. 524, pp. 3573-3577. Trans Tech Publications Ltd. Retrieved from: https://www.scientific.net/AMR.524-527.3573

8. Semenyuk, E.P. (2012) Role of informatics in the ecologization of society. Scientific and Technical Information Processing, 39(1), 1-12. DOI: https://doi.org/10.3103/S0147688212010029

9. Dubodielova, A.V., Yurynets, O.V., Fedoriv, M.M. (2011) Orhanizatsiino-ekonomichni mekhanizmy ekolohizatsii vyrobnytstva na vitchyznianykh pidpryiemstvakh Organizational and economic mechanisms of greening production at domestic enterprises]. Visnyk Natsionalnoho universytetu «Lvivska politekhnika», 698, 156-162.

10. Hobela, V.V. (2021) Ekonomiko-bezpekova ekolohizatsiia: teoriia i praktyka [Economic and security greening: theory and practice]. Lviv: LvDUVS. (in Ukrainian)

11. Zaichenko K.S., Dima N.I. (2021) Economic security of the enterprise: essence and role. Efficient economy, 5. Retrieved from: http://www.economy.nayka.com.ua/?op=1\&z=8900 (in Ukrainian)

12. Marushevskyi H., Khikman Dah. (2017) «Zelenyi» biznes dlia malykh i serednikh pidpryiemstv ["Green" business for small and medium enterprises]. Retrieved from: http://pleddg.org.ua/wp-content/uploads/2017/11/SMEGuide-web.pdf (in Ukrainian)

13. Baliuk, S., Klauninh N., Chetvertukhina L., \& Koval-Honchar M. (2021) Ekolohichni trendy v Ukraini: pohliad hromadian. Zvit za rezultatamy sotsiolohichnoho doslidzhennia [Environmental trends in Ukraine: the view of citizens. Report on the results of sociological research]. Retrieved from: http://library.fes.de/pdf-files/bueros/ukraine/17805.pdf (in Ukrainian)

14. Kuts, N. (2020) Ekolohichna svidomist ukraintsiv \& dovkillia [Ecological consciousness of Ukrainians \& environment]. Retrieved from: http://epl.org.ua/wp-content/uploads/2020/12/ekosvidomist.pdf (in Ukrainian)

15. Prokopenko, O.V. (2010) Sotsialno-ekonomichna motyvatsiia ekolohizatsii innovatsiinoi diialnosti [Socioeconomic motivation of greening of innovative activities]. Sumy: Vyd-vo SumDU. (in Ukrainian) 